\title{
How Does Falling Relate to Fatigue, Fear of Falling, Mood and Quality of Life in Pregnancy?
}

\section{Gebelerde Düşme ile Yorgunluk, Düşme Korkusu, Duygu Durumu ve Yaşam Kalitesi Arasındaki İlişki}

\section{(D İlknur Can1, (D) Betül Keyif2}

1İstanbul Medipol University Faculty of Medicine, Department of Physical Medicine and Rehabilitation, İstanbul, Turkey

${ }^{2}$ Kestel State Hospital, Clinic of Gynecology and Obstetrics, Bursa, Turkey

\section{Abstract}

Objective: There are many studies on the impact of physical changes on pregnancy falls. We conducted this study to investigate the effects of mental changes as well as physical changes on pregnancy fall. Therefore, we evaluated how people who fell during pregnancy were related to fatigue, fear of falling, mood and health-related quality of life.

Method: Pregnant women were divided into 2 groups as those who falled (group 1) and those who did not (group 2). Pregnant women in both groups were tested to stand on one leg, and the following forms were filled: fatigue severity scale (FSS), Beck depression inventory (BDI), falls efficacy scale international (FES), and Nottingham health profile (NHP). The groups were compared based on the data obtained.

Results: FSS (group 1: $4.9 \pm 1.6$, group 2: $4.0 \pm 1.8, p=0.002$ ), BDI (gsroup 1: $23.9 \pm 12.5$, group 2: $10.8 \pm 7.3, p<0.001$ ), FES (group 1: $39.5 \pm 10.5$, group 2: $26.6 \pm 6.6, p<0.001$ ), and NHP (group 1: $321.9 \pm 123.1$, group 2: $189.4 \pm 96.1$ $p<0.001)$ were found to be significantly higher in group 1. FES was positively correlated with $\mathrm{FSS}, \mathrm{BDI}$ and $\mathrm{NHP}$, and significantly negatively correlated with the test of standing on one leg. The test of standing on one leg was negatively correlated with FES, FSS, BDI and NHP.

Conclusion: This study shows that mental changes as well as physical changes can have an impact on falls and balance in pregnant women.

Keywords: Depression, fall, fatigue, pregnancy, quality of life

\section{Öz}

Amaç: Fiziksel değişikliklerin hamilelik düşmeleri üzerindeki etkisi üzerine pek çok çalışma bulunmaktadır. Bu çalışma fiziksel değişikliklerin yanı sıra zihinsel değişikliklerin de gebelikte düşme üzerindeki etkilerini araştırmak için yapıldı. Bu amaçla hamilelik sırasında düşen kişilerin yorgunluk, düşme korkusu, ruh hali ve sağlıkla ilişkili yaşam kalitesi ile nasıl ilişkili olduğunu değerlendirdik.

Yöntem: Gebe kadınlar düşenler (grup 1) ve düşmeyenler (grup 2) olarak iki gruba ayrıldı. Her iki gruptaki gebelere tek ayak üzerinde durma testi yapılarak ve yorgunluk şiddet ölçeği (FSS), Beck depresyon envanteri $(B D E)$, uluslararası düşme etkinlik ölçeği (FES), Nottingham sağılk profile (NSP) formları dolduruldu. Elde edilen veriler gruplar arasında karşılaştırıldı.

Bulgular: FSS (grup 1: 4,9 $\pm 1,6$, grup 2: 4,0 $\pm 1,8, p=0,002$ ), BDE (grup 1: $23,9 \pm 12,5$, grup 2: $10,8 \pm 7,3, p<0,001$ ), FES (grup 1: $39,5 \pm 10,5$, grup 2: $26,6 \pm 6,6, p<0,001$ ), NSP (grup 1: $321,9 \pm 123,1$, grup 2: 189,4 $\pm 96,1, p<0,001$ ) skorları grup 1'de anlamlı yüksek bulundu. Korelasyon analizinde FES ile, FSS, BDE ve NSP arasında pozitif yönde ve tek ayakta durma testi arasında negatif yönde anlamlı ilişki vardı. Tek ayak üstünde durma testi ile FES, FSS, BDE ve NSP arasındaki negatif yönde ilişki anlamlı idi.

Sonuç: Bu çalışma, fiziksel değişikliklerin yanı sıra zihinsel değişikliklerin hamile kadınlarda düşme ve denge üzerinde etkili olabileceğini göstermektedir.

Anahtar kelimeler: Depresyon, düşme, gebelik, yaşam kalitesi yorgunluk

Address for Correspondence: Illknur Can, İstanbul Medipol University Faculty of Medicine, Department of Physical Medicine and Rehabilitation, İstanbul, Turkey

E-mail: drilknurcann@gmail.com ORCID: orcid.org/0000-0002-5904-2980 Received: 19.03.2021 Accepted: 22.05.2021

Cite this article as: Can I, Keyif B. How Does Falling Relate to Fatigue, Fear of Falling, Mood and Quality of Life in Pregnancy? Bagcilar Med Bull 2021;6(3):229-233

${ }^{\circ}$ Copyright 2021 by the Health Sciences University Turkey, Bagcilar Training and Research Hospital Bagcilar Medical Bulletin published by Galenos Publishing House. 


\section{Introduction}

Adaptive changes occur in the musculoskeletal system as well as in many tissues and organs during pregnancy, depending on the increasing metabolic needs of the fetus and mother. Increased weight of the fetus and its posture cause excessive loading of the lumbar spine and abdominal muscles. This changes the body's center of gravity, resulting in an increase in the posterior direction of the position of the pregnant woman's head, anterior pelvic tilting and lumbar lordosis $(1,2)$. In addition to changes in posture, weight gain, memory difficulties and concentration problems, increased laxity in ligaments, swelling in the hands and feet, reduced neuromuscular control, and changes in body biomechanics due to adaptations in soft tissues and joints may affect the balance in pregnant women and cause them to fall (3). Studies have reported that about $25-26 \%$ of pregnant women fall at least once during pregnancy, and this happens most frequently in the third trimester $(4,5)$. Pregnant women have a higher risk of falling and injury than non-pregnant women. Falling during pregnancy has a broad spectrum of effects ranging from simple results such as joint sprains and muscle injuries to bone fractures, head traumas, visceral organs ruptures, internal bleeding, premature birth, sudden placental and uterine ruptures, early rupture of membranes, and maternal and fetal death $(1,2)$.

There may be changes in physical and mental health that can reduce the quality of life in pregnant women. Pregnant women may experience hormonal changes triggering symptoms of nausea and vomiting, sleep disturbances, anxiety, depression, low energy and fatigue (6). Such situations can act as a trigger for falls by affecting the sensory motor organization needed for the postural balance (7).

In our study, we aimed to assess how falling was related to fatigue, fear of falling, mood and health-related quality of life of people falling during pregnancy.

\section{Materials and Methods}

After the approval of the local ethics committee (ethics committee no: 2019/01), 130 pregnant women who presented to the gynecology outpatient clinic between February and June 2019 were included in our study.

The study included 18-45-year-old women pregnant with a single baby in the third trimester, who did not have a risky pregnancy or any neurological conditions that had an effect on balance. Those who had fallen at least once during their pregnancy were assigned into the first group and those who had never fallen into the second group. Pregnant women who had not fallen in the second group were followed until the end of pregnancy, and 2 people who fell during the study were assigned into the group of people who had fallen. The study was concluded with 67 patients in group 1 and 63 patients in group 2.

All pregnant women were tested for standing on one leg (8). The fatigue severity scale (FSS) was filled to assess the level of fatigue, the Beck depression inventory (BDI) to assess mood, the falls efficacy scale (FES) to assess the fear of falling, and the Nottingham health profile (NHP) to assess the quality of life, all of which had been tested for validity and reliability in Turkish (9-12).

Test of standing on one leg: This is a test that assesses the balance and risk of falling of patients. Patients are told to maintain their balance by standing up while lifting one leg up, keeping their hip in neutral position and their knee at 90-degree flexion. The upper limit in the test is accepted to be 30 seconds, and the test is terminated for of pregnant women who complete this period. Those who complete the test under 10 seconds have balance disorder, and those who complete the test in less than 5 seconds are at risk of falling.

FSS: This is a scale that measures people's level of fatigue. People specify how much they consent to each item by choosing a number from 1 to 7 . The score range of the scale consisting of a total of 9 questions is from 9 to 63. A score of 36 or higher shows severe fatigue (9).

BDI: The BDI is made up of 21 questions. Each question is scored between 0 and 3 . A score of 21 or higher is considered as a diagnosis of clinical depression (10).

FES: This is a test consisting of 16 questions that measure people's fear of falling. People are asked how safe they feel when performing simple daily living activities and are asked to mark it on paper from 1 to 10 ( 1 is completely unsafe, 10 is extremely safe). A score between 0 and 100 in total is obtained to assess their fear of falling (11).

NHP: This is a general health survey of 38 items that assess the quality of life. Six sub-parameters made up of energy level, emotional reactions, physical activity (PA9, pain, sleep and social isolation and total points are assessed. The answers to the questions are marked as "yes" or "no." The total score ranges from 0 to 600 , and a high health-related quality of life perception is inversely proportional to the score obtained (12).

The specified tests and scales were administered to both groups, and the groups were compared based on the data obtained. 


\section{Statistical Analysis}

SPSS (Statistical Package for Social Science) program version 22.0.0 was used for statistical analysis. Confidence interval was accepted as $95 \%$. The normality of the data was analyzed using the Kolmogorov-Smirnov test. The Levene's test was used to determine the homogeneity and equality of variances. The Student's t-test and the Mann-Whitney $\mathrm{U}$ test were used when comparing the groups in terms of quantitative data. The Pearson's chi-square test was used when comparing the groups in terms of qualitative data. Correlation analysis was conducted using the Pearson correlation method. The statistical significance level was accepted as $\mathrm{p}<0.05$. Results were presented as mean \pm standard deviation.

\section{Results}

There was no significant difference between the groups in terms of average age, body mass index, gestational week and demographic data. Group 1 showed significantly worse performance in the test of standing on one leg compared to group 2, while they had significantly higher scores on the FSS, BDI, and the FES. On the other hand, they had significantly higher scores on the NHP, which is inversely proportional to the score of perception of high quality of life related to health (Table 1).

FES was positively correlated with FSS, BDI and NHP, and significantly negatively correlated with the test of standing on one leg. The test of standing on one leg was correlated negatively with FES, FSS, BDI and NHP (Table 2).

Table 1. Comparison between the pregnant women who had fallen and who had not

\begin{tabular}{lll} 
& Group 1 $(\mathbf{n = 6 7 )}$ & Group 2 $(\mathbf{n = 6 3})$ \\
\hline Weight & $70.5 \pm 12.4$ & $71.6 \pm 9.5$ \\
Height & $158.5 \pm 6.6$ & $160.8 \pm 5.6$ \\
BMI & $28.0 \pm 4.4$ & $27.6 \pm 3.2$ \\
Age & $27.0 \pm 6.5$ & $26.6 \pm 6.5$ \\
Gestational week & $29.8 \pm 7.8$ & $31.1 \pm 6.8$ \\
FES & $39.5 \pm 10.5^{* *}$ & $26.6 \pm 6.6^{* *}$ \\
FSS & $4.9 \pm 1.6^{*}$ & $4.0 \pm 1.8^{*}$ \\
BDI & $23.9 \pm 12.5^{* *}$ & $10.8 \pm 7.3^{* *}$ \\
NHP & $321.9 \pm 123.1^{* *}$ & $189.4 \pm 96.1^{* *}$ \\
Test of standing on & $15.7 \pm 12.1^{* *}$ & $22.7 \pm 8.6^{* *}$ \\
one leg & & \\
\hline
\end{tabular}

Results are presented as mean \pm standard deviation, ${ }^{*} p<0.05,{ }^{* *} p<0.01$, BMI: Body mass index, FSS: Fatigue severity scale, BDI: Beck depression inventory, NHP: Nottingham health profile, FES: Falls efficacy scale international

\begin{tabular}{llllll}
\multicolumn{7}{l}{ Table 2. Correlation analysis results } \\
& FES & FSS & BDI & NHP & $\begin{array}{l}\text { Test of } \\
\text { standing } \\
\text { on one leg }\end{array}$ \\
\hline FES & 1 & $0.442^{* *}$ & $0.738^{* *}$ & $0.713^{* *}$ & $-0.355^{* *}$ \\
FSS & $0.442^{* *}$ & 1 & $0.511^{* *}$ & $0.480^{* *}$ & $-0.298^{* *}$ \\
BDI & $0.738^{* *}$ & $0.511^{* *}$ & 1 & $0.705^{* *}$ & $-0.257^{* *}$ \\
NHP & $0.713^{* *}$ & $0.480^{* *}$ & $0.705^{* *}$ & 1 & $-0.368^{* *}$ \\
$\begin{array}{l}\text { Test of } \\
\text { standing on } \\
\text { one leg }\end{array}$ & $-0.355^{* *}$ & $-0.298^{* *}$ & $-0.257^{* *}$ & $-0.368^{* *}$ & 1 \\
\hline
\end{tabular}

FSS: Fatigue severity scale, BDI: Beck depression inventory, NHP: Nottingham health profile, FES: Falls efficacy scale international, ${ }^{* *} p<0.01$

\section{Discussion}

Our study is a study the argues that psycho-social changes in pregnancy, as well as physical changes, may have an impact on falls. In this context, we examined how falling was related to fatigue, depression, fear of falling and quality of life. First of all, pregnant women who had fallen performed significantly worse in the test of standing on one leg. This is the expected outcome considering the impact on balance of physical changes in pregnancy. Second, fatigue, depression and fear of falling among the pregnant women who had fallen were significantly higher. Moreover, the health-related quality of life was lower.

Postural balance is a complex process generated by the coordination of vestibular, somato-sensory and visual inputs at the central nervous system level (13). All these systems need to work in coordination to achieve balance. In addition to physical changes in pregnancy, somato-sensory and psychosomatic changes may also play a role in balance and falls. Previous studies have shown that anxiety may be associated with balance disorders. Wada et al. (14) reported in their study on anxiety levels on college students that the degree of anxiety affected anteroposterior oscillation while eyes were open. Nagai et al. (15) showed that high anxiety during pregnancy caused imbalance while standing with eyes open. This decreased when the eyes were closed. In this study, it was emphasized that the pregnant women balanced current physical difficulties using somatosensory cues and achieved their balance thus. In our study, we found higher scores of fatigue, depression and fear of falling among the pregnant women who had fallen. The health-related quality of life of these people was also worse. According to these results, we can say that pregnant women who are psychosomatically affected and have a poorer sense of quality of life are more prone to falling. 
While there are few studies assessing the impact of psychosomatic processes on balance, the relationship between psychological processes and balance remains unclear. In the study of Bolmont et al. (16), healthy male students were subjected to a 12-day balance test program while their daily mood and anxiety levels were examined. The study also involved an investigation of how balance was related to emotions such as depression, fatigue, vitality, confusion, and anger/aggressiveness, in addition to anxiety. The Global Sensory Organization test, which demonstrated the ability to use inputs from the sensory system, was found to have a positive correlation with anxiety, depression and anger scores. A negative correlation was found between the ability to evaluate somato-sensory inputs and anxiety, between the ability to evaluate visual inputs and depression and anger/aggressiveness, between the ability to evaluate vestibular inputs and anxiety, depression and anger/ aggressiveness. There was a positive correlation between vitality and the ability to evaluate vestibular inputs. Motor control test performances showed a negative correlation with fatigue and tension. This study has shown that they can influence the ability to use data from the somato-sensory visual or vestibular system to maintain balance. It has also shown that low mood can change balance performance, causing falls. Similarly, higher levels of fatigue, depression and fear of falling were observed in our study, too, while the quality of life was significantly lower among the pregnant women who had fallen. The correlation analysis showed that the test of standing on one leg had a significant and negative correlation with the fear of falling, fatigue, depression and NHP.

Although many studies have been carried out on postpartum depression, research associated with pregnancy depression is limited. The incidence of depression in pregnancy is between $25 \%$ and $30 \%$ on average in these studies (17). Anxiety and depression have been shown to occur more prominently in the first and third trimesters of pregnancy compared to the second trimester (17). During pregnancy, sleep and appetite changes, fluctuations in conditions of sensation and anxiety, excessive fatigue, loss of libido, and difficulty in concentration may be observed. These negative changes can have a negative effect on the processing of somato-sensory inputs in the pregnant woman, which can cause falls. In our study, we found that depression scores were significantly higher among the pregnant group who had fallen. Moreover, we found that depression was positively correlated with fear of falling, fatigue, and poor quality of life.
A number of studies have investigated the relationship between changes in postural stability and disorders occurring during pregnancy (17-20). It has been observed that pregnant women with morning sickness reduce body oscillation in order to control dizziness and other symptoms (18). Deterioration in postural stability and the risk of falling have also been reported to be increased in pregnant women diagnosed with hyperemesis gravidarum, which is a heavier form of morning sickness (20). A vast majority of pregnant women (87.2-96.5\%) complain of fatigue and exhaustion (21). More pronounced fatigue occurs at night. Fatigue begins in weeks 11 and 12 and reaches the highest levels in the third trimester. Prenatal fatigue has also been found to be related to depression, anxiety and premature birth (21). In other words, maternal stress and fatigue have a similar effect on pregnant women's well-being. The level of fatigue in our study was higher in the group of pregnant women who had fallen. Fatigue can impair somato-sensory inputs as well as reducing physical performance, causing falls.

Memory loss and attention issues are two physiological changes that arise during pregnancy, along with fatigue (22). A reduction in visuospatial working memory and executive functions has also been linked to maternal depression and anxiety (23). The importance of a decrease in visuospatial memory is not only related to spatial skills, but it may also cause the mother to fall by affecting her ability to perceive and respond to changes in the environment quickly. There is a need for extensive studies in this regard.

\section{Study Limitations}

This is a cross-sectional study, and all patients were selected from among patients at a single center, who were in their $3^{\text {rd }}$ trimester. The sample size can be increased. Notwithstanding these limitations, our study is important to show that somato-sensory inputs can impact falls in pregnancy.

\section{Conclusion}

We have presented the first study exploring how falling in pregnancy is related to depression, fatigue, fear of falling, and changes in quality of life. These parameters can affect the somato-sensory organization of balance in pregnant women, which can increase the frequency of falls. Simple tests can easily identify patients who may have a low quality of life, excessive fatigue, or depression. In these patients, both the level of depression and fatigue can be reduced, and the quality of life is improved through psychotherapeutic 
interventions, by arranging exercise programs such as pregnancy Pilates, balance and resistance exercises, aerobic exercises, yoga, and tai chi to improve balance. All of these interventions can help pregnant women avoid falling. Further studies on this issue involving larger samples and longer follow-up periods are needed.

\section{Ethics}

Ethics Committee Approval: Van Regional Training and Research Hospital received ethical approval from the NonInterventional Research Ethics Committee on 3.1.2019, numbered 2019/01.

Informed Consent: An informed consent form was obtained from the patients.

Peer-review: Externally peer-reviewed.

\section{Authorship Contributions}

Concept: İ.C., Design: İ.C., Data Collection or Processing: B.K., Analysis or Interpretation: İ.C., Drafting Manuscript: İ.C., B.K., Supervision: İ.C., B.K., Writing: İ.C.

Conflict of Interest: No conflict of interest was declared by the authors.

Financial Disclosure: The authors declared that this study has received no financial support.

\section{References}

1. Çakmak B, Ribeiro AP, İnanir A. Postural balance and the risk of falling during pregnancy. J Matern Fetal Neonatal Med 2016;29(10):1623-1625.

2. Bertuit J, Leyh C, Rooze M, Feipe V. Pregnancy-related changes in center of pressure during gait. Acta Bioeng Biomech 2017;19(4):95102.

3. McCroryJL, Chambers AJ, Daftary A. Redfern MS. Dynamic postural stability in pregnant fallers and non-fallers. BJOG 2010;117(8):954962.

4. Dunning K, Le Masters G, Bhattacharya A. A major public health issue: the high incidence of falls during pregnancy. Matern Child Health J 2010;14(5):720-725.

5. Danna-Dos-Santos A, Magalhães AT, Silva BA, Duarte BS, Barros G, Silva MDFC, et al. Upright balance control strategies during pregnancy. Gait Posture 2018;66:7-12.

6. O'Connor PJ, Poudevigne MS, Johnson KE, Araujo JB, Ward-Ritacco CL. Effects of resistance training on fatigue-related domains of quality of life and mood during pregnancy: a randomized trial in pregnant women with back pain. Psychosom Med 2018;80(3):327332.

7. Bolmont B, Gangloff P, Vouriot A, Perrin PP. Moodstates and anxiety influence abilities to maintain balance control in healthy human subjects, Neurosci Lett 2002;329(1):96-100.

8. Vellas BJ, Wayne SJ, Romero L, Baumgartner RN, Rubenstein LZ, Garry PJ. One-leg balance is an important predicotr of injurious falls in older persons. J Am Geriatr Soc 1997;45(6):735-758.
9. Armutlu K, Korkmaz NÇ, Keser İ, Sumbuloglu V, Akbiyik ID, Guney $\mathrm{Z}$, et al. The validity and reliability of the Fatique Severity Scale in Turkish multiple sclerosis patients. Inter J Rehab Res 2007;30(1):8185.

10. Hisli N. Beck depresyon envanterinin üniversite öğrencileri için geçerliliği ve güvenirliliği. Psikoloji Dergisi 1989;7(23):3-13.

11. Ulus Y, Durmus D, Akyol Y, Terzi Y, Bilgici A, Kuru O. Reliability and validity of the Turkish version of the Falls Efficacy Scale International (FES-I) in community-dwelling older persons. Arch Gerontol Geriatr 2012;54(3):429-433.

12. Kücükdeveci AA, McKenna SP, Kutlay S, Gürsel Y, Whalley D, Arasil T. The development and psychometric assessment of the Turkish version of the Nottingham Health Profile. Int J Rehabil Res 2000;23(1):31-38.

13. Paulus W, Straube A, Brandt T. Visual postural performance after loss of somatosensory and vestibular function. J Neurol Neurosurg Psychiatry 1987;50(11):1542-1545.

14. Wada M, Sunaga N, Nagai M, Anxiety affects the postural sway of the antero-posterior axis in college students. Neurosci Lett 2001;302(2-3):157-159.

15. Nagai $M$, Isida $M$, Saitoh J, Hirata $Y$, Natori $H$, Wada $M$. Characteristics of the control of standing posture during pregnancy. Neurosci Lett 2009;462(2):130-134.

16. Bolmont P, Gangloff A, Vouriot PP. Perrin, mood states and anxiety influence abilities to maintain balance control in healthy human subjects. Neurosci Lett 2002;329(1):96-100.

17. Schetter CD, Tanner L. Anxiety, depression and stress in pregnancy: implications for mothers, children, research, and practice. Curr Opin Psychiatry 2012;25(2):141-148.

18. Yu Y, Chung HC, Hemingway L, Stoffregen TA. Standing body sway in females with and without morning sickness in pregnancy. Gait Posture 2013;37(1):103-107.

19. Workman JL, Barha CK, Galea LAM. Endocrine substrates of cognitive and affective changes during pregnancy and postpartum. Behav Neurosci 2012;126(1):54-72.

20. Çakmak B, Inanir A, Nacar MC. Postural balance in pregnancies complicated by hyperemesis gravidarum. J Matern Fetal Neonatal Med 2015;28(7):819-22.

21. Cheng CY, Pickler RH. Perinatal stress, fatigue, depressive symptoms, and immune modulation in late pregnancy and one month postpartum. Scientific World Journal 2014;2014:652630. doi: 10.1155/2014/652630.

22. Logan DM, Hill KR, Jones R, Holt-Lunstad J, Larson MJ. How do memory and attention change with pregnancy and childbirth? A controlled longitudinal examination of neuropsychological functioning in pregnant and postpartum women. J Clin Exp Neuropsychol 2014;36(5):528-539.

23. Kataja EL, Karlsson L, Huizink AC, Tolvanen M, Parsons C, Nolvi $S$, et al. Pregnancy-related anxiety and depressive symptoms are associated with visuospatial working memory errors during pregnancy. J Affect Disord 2017;218:66-74. 